\title{
PENINGKATAN PEMAHAMAN MAHASISWA TERHADAP MATA KULIAH PENGANTAR AKUNTANSI DENGAN STRATEGI PENINJAUAN KEMBALI MELALUI PERMAINAN DALAM KELAS
}

\author{
Febrina Nafasati P. \\ Dian Indudewi
}

Diterima: Agustus 2019, Disetujui: September 2019, Dipublikasikan: Oktober 2019

\begin{abstract}
This study aims to test the effectiveness of the implementation of the strategy through the game reconsideration presented in the classroom and learning process in improving the learning ability of students. As well as proving whether a review of the strategy through the game in the classroom can improve student comprehension and liveliness in the learning process.

This research was carried out on the S-1 Regular Student Accounting Department University of Semarang who took a course Introduction to Accounting. Review of the implementation of the strategy implemented in two cycles. The first cycle was held on the matter "accounting equation 'using Hollywood-Square games. While the material held on the second cycle "general journal" using games or Jigsaw. At each cycle performed pre-test and post-test to see the results of a review of the strategy implementation.

The results empirically showed that the application of proven strategies to improve review of students' understanding of the course material provided. This is evident from the increase of student achievement results, with an increase in the value of the post-test compared to pre-test values both in the first cycle and the second cycle.

Keywords: Strategy judicial review, cycle one, cycle two, the game Hollywood Square, Jigsaw game.
\end{abstract}

\section{Abstrak}

Penelitian ini bertujuan untuk menguji efektivitas penerapan strategi peninjauan kembali melalui permainan dalam kelas yang disajikan pada proses belajar mengajar dalam meningkatkan kemampuan belajar mahasiswa. Serta membuktikan apakah strategi peninjauan kembali melalui permainan dalam kelas dapat meningkatkan pemahaman dan keaktifan mahasiswa dalam proses belajar mengajar.

Penelitian ini dilaksanakan pada mahasiswa S-1 Reguler Jurusan Akuntansi Universitas Semarang yang mengambil mata kuliah Pengantar Akuntansi. Pelaksanaan strategi peninjauan kembali dilaksanakan dalam dua siklus. Siklus pertama dilaksanakan pada materi"persamaan akuntansi' dengan menggunakan permainan ala Holly-wood Square. Sedangkan siklus kedua dilaksanakan pada materi "jurnal umum" dengan menggunakan permaianan Jigsaw. Pada setiap siklus dilaksanakan pre-test dan post-test untuk melihat hasil dari penerapan strategi peninjauan kembali.

Hasil penelitia ini menunjukkan bahwa penerapan strategi peninjauan kembali terbukti dapat meningkatan pemahaman mahasiswa terhadap materi perkuliahan yang diberikan. Hal ini terlihat dari peninkatan hasil prestasi belajar mahasiswa, dengan terjadinya peningkatan nilai post-test dibandingkan dengan nilai pre-test baik pada siklus pertama maupun pada siklus kedua.

Kata kunci : Strategi Peninjauan Kembali, Siklus satu, Siklus dua, permainan Hollywood Square, permainan Jigsaw 


\section{PENDAHULUAN}

Pengantar Akuntansi merupakan mata kuliah yang wajib disampaikan kepada mahasiswa Jurusan Akuntansi. Mata kuliah ini merupakan mata kuliah pokok yang wajib diikuti oleh semua mahasiswa pada program studi akuntansi. Mata kuliah ini memberikan pemahaman dan pengetahuan tentang dasar akuntansi keuangan, persamaan akuntansi, teknik pemrosesan data akuntansi yang meliputi jurnal, buku besar, worksheet serta dasar penyusunan laporan keuangan baik untuk perusahaan jasa,, dagang, maupun manufaktur. Setelah menyelesaikan mata kuliah ini mahasiswa diharapkan memiliki pemahaman dan pengetahuan tentang dasar akuntansi keuangan, sehingga dapat menyusun laporan keuangan perusahaan dagang, jasa, dan manufaktur.

Bagi mahasiswa akuntansi tidak ada pilihan lain buat mereka untuk memahami betul mata kuliah satu ini, karena mata kuliah ini memegang peranan utama dan menentukan dalam mengantarkan para mahasiswa yang akan mempelajari akuntansi dan mata kuliah lain yang berkaitan pada tahapan berikutnya. Namun, sangat disayangkan ketika masih banyak kita jumpai mahasiswa akuntansi yang kurang memahami betul mata kuliah dasar ini, sebagai pegangan mereka. Banyak diantara mahasiswa yang masih belum memahami pengertian dari akuntansi, banyak diantara mereka juga yang masih belum memahami bagaiaman membuat jurnal apalagi menyusun laporan keuangan (mstakimch, 2012).

Proses belajar mengajar yang selama ini dilaksanakan oleh pengajar (dosen) adalah dengan penyampaian materi melalui metode ceramah dan pemberian tugas terstruktur yang menunjang pemahaman kognitif mahasiswa. Proses belajar mengajar seperti ini mengakibatkan mahasiswa cenderung menghafalkan materi sebagai cara yang mudah untuk memahami. Pemahaman atas keterkaitan logis antar konsep, teori, aspek teknik kurang ditekankan secara efektif sehingga mahasiswa cenderung menghafal, kurang kreatif, dan sulit mengembangkan kemampuan kognitifnya. Kecenderungan mahasiswa menghafal pada proses belajar mengajar mata kuliah Pengantar Akuntansi akan menghadapi masalah karena materi pengantar akuntansi menuntut pemahaman mahasiswa. Oleh karena itu diperlukan metode pembelajaran yang mampu meningkatkan kemampuan belajar mahasiswa sangat diperlukan. Upaya meningkatkan pemahaman terhadap materi pengantar akuntansi dapat dilakukan melalui strategi peninjauan kembali. Salah satu cara untuk membuat pembelajaran tetap melekat dalam pikiran adalah dengan mengalokasikan waktu untuk meninjau kembali apa yang telah dipelajari. Materi yang telah dibahas oleh mahasiswa cenderung lima kali lebih melekat di dalam pikirannya. Itu karena pembahasan kembali memungkinkan mahasiswa untuk memikirkan kembali informasi tersebut dan menemukan cara untuk menyimpannya di dalam otak. Strategi peninjauan kembali selain menjadi aktif, dapat menjadikan peninjauan kembali sebagai aktivitas yang menyenangkan (Melvin L. Silberman, 2006)..

Berdasarkan uraian latar belakang diatas, maka perumasan masalah dalam penelitian ini adalah apakah dengan proses belajar mengajar mata kuliah Pengantar Akuntansi melalui strategi peninjauan kembali melalui permainan dalam kelas dapat meningkatkan kemampuan, pemahaman dan keaktifan mahasiswa dalam proses belajar mengajar.

Sesuai dengan rumusan masalah, penelitian ini mempunyai tujuan untuk menguji efektivitas penerapan strategi peninjauan kembali melalui permainan dalam kelas yang disajikan pada proses belajar mengajar mata kuliah Pengantar Akuntansi 
dalam meningkatkan kemampuan belajar mahasiswa. Dan membuktikan apakah strategi peninjauan kembali melalui permainan dalam kelas pada mata kuliah Pengantar Akuntansi dapat meningkatkan pemahaman dan keaktifan mahasiswa dalam proses belajar mengajar.

Hasil dari pelaksanaan penelitian ini diharapkan dapat memberikan manfaat yang berarti yaitu bagi mahasiswa, untuk meningkatkan kemampuan belajar, pemahaman dan keaktifan dalam mata kuliah Pengantar Akuntansi. Bagi dosen, penelitian ini bermanfaat untuk mengembangkan rancangan pembelajaran yang dapat meningkatkan kemampuan belajar mahasiswa dalam kegiatan belajar mengajar khususnya dalam mata kuliah Pengantar Akuntansi. Bagi pengembangan institusi, penelitian ini diharapkan menjadi salah satu implementasi Penelitian Pengembangan Pembelajaran sebagai lembaga ilmiah yang dituntut melakukan inovasi pendidikan yang dapat dipertanggungjawabkan secara ilmiah.

\section{TINJAUAN PUSTA}

\section{Konsep Belajar dan Prestasi Belajar}

Belajar merupakan proses internal komplek. Hal ini karena melibatkan seluruh aspek mental, yang meliputi ranah kognitif, aktif, dan psikomotorik. Dalam proses belajar, dosen dapat mengamati secara langsung proses internal mahasiswa. Proses belajar tersebut merupakan respon mahasiswa terhadap tindakan belajar dan mengajar dari dosen (Dimyati dan Mudjiono, 2002 dalam Indah, 2011). Prestasi merupakan hasil yang dicapai seseorang ketika mengerjakan tugas atau kegiatan tertentu. Prestasi akademik adalah hasil belajar yang diperoleh dari kegiatan pembelajaran di sekolah atau di perguruan tinggi yang bersifat kognitif dan biasanya ditentukan melalui pengukuran dan penilaian. Sementara prestasi belajar adalah penguasaan pengetahuan atau keterampilan yang dikembangkan oleh mata kuliah, lazimnya ditunjukkan dengan nilai tes atau angka yang diberikan oleh dosen (Tulus, 2004 dalam Indah, 2011).

Prestasi belajar mahasiswa dipengaruhi banyak faktor baik yang berasal dari faktor intern maupun faktor ekstern mahasiswa. Faktor intern adalah faktor yang ada dalam diri individu yang sedang belajar, sedangkan faktor ekstern adalah faktor yang ada di luar individu. Faktor intern meliputi: (a) faktor jasmaniah, (b) faktor psikologis, dan (c) faktor kelelahan. Sedangakan faktor ekstern meliputi: (a) faktor keluarga, (b) faktor sekolah/ lembaga pendidikan, dan (c) faktor masyarakat (Slameto, 2003 dalam Indah, 2011).

\section{Belajar Kelompok (Cooperative Learning)}

Asnida, (2006) dalam Indah (2011) menyatakan bahwa pembelajaran kooperatif (cooperative learning) telah menjadi salah satu pembaharuan dalam pergerakan refomasi pendidikan. Pembelajaran kooperatif sebenarnya merangkum banyak jenis bentuk pengajaran dan pembelajaran. Asasnya ialah menggalakkan mahasiswa belajar bersama-sama dengan berkesan melalui pembentukan komponen yang homogen seperti dalam pendidikan inklutif. Pembelajaran kooperatif atau belajar kelompok boleh digunakan oleh berbagai kelompok umur dan dalam perbagai mata pelajaran. Pembelajaran kooperatif (cooperative learning) dilaksanakan pada kelompok kecil supaya mahasiswa dapat berkerja sama dalam kelompok tersebut untuk mempelajari isi kandungan pelajaran dengan berbagai kemahiran sosial. 

2011):

Beberapa strategi meningkatkan pembelajaran kooperatif yang berkesan (Indah,

a. Pembagian kelompok yang memperbolehkan anggota-anggota dalam kelompok bekerja sama.

b. Tugas harus dibuat terstruktur supaya anggota kelompok saling bergantung untuk mencapai objektif yang ditentukan.

c. Jadikan tanggung jawab pencapaian terletak di kedua tahap individu dan kelompok. Salah satu cara ialah melalui pemberian tugas. Setiap mahasiswa mendapat tugas individu, dan tugas kelompok bergantung kepada tugas individu.

d. Berikan garis panduan tingkah laku dan kemahiran berkomunikasi kepada mahasiswa. Pengajar perlu menjelaskan kepada mahasiswa bagaimana cara berkomunikasi yang baik misalnya bagaimana mengeluarkan pendapat dan bagaimana menghadapi pendapat yang berbeda.

e. Pastikan jenis dan kemauan interaksi antara mahasiswa bertautan. Pengajar harus mengawasi interaksi yang berjalan antar mahasiswa dalam menjalankan aktivitas kelompok di dalam kelas.

\section{Strategi Peninjauan Kembali}

Strategi Peninjauan Kembali membahas cara-cara untuk membantu mahasiswa mengingat apa yang telah mereka pelajari dan menguji pengetahuan dan kemampuan mereka yang sekarang. Pengajar akan menjumpai strategi peninjauan kembali yang menarik bagi mahasiswa dan membantu "menyimpan" pembelajaran yang telah mereka terima (Indah, 2011). Menurut Melvin L. Silberman, (2006) dalam Indah, (2011) mengungkapkan bahwa materi yang telah dibahas oleh mahasiswa cenderung lima kali lebih melekat di dalam pikirannya. Itu karena pembahasan kembali memungkinkan mahasiswa untuk memikirkan kembali informasi tersebut dan menemukan cara untuk menyimpannya di dalam otak.

\section{Hubungan Logis Variabel}

Salah satu cara untuk membuat pembelajaran tetap melekat dalam pikiran adalah dengan mengalokasikan waktu untuk meninjau kembali apa yang telah dipelajari. Materi yang telah dibahas oleh mahasiswa cenderung lima kali lebih melekat di dalam pikirannya. Itu karena pembahasan kembali memungkinkan mahasiswa untuk memikirkan kembali informasi tersebut dan menemukan cara untuk menyimpannya di dalam otak. Strategi peninjauan kembali selain menjadi aktif, dapat menjadikan peninjauan kembali sebagai aktivitas yang menyenangkan (Melvin L. Silberman, 2006 dalam Indah, 2011).

Strategi Peninjauan Kembali membahas cara-cara untuk membantu mahasiswa mengingat apa yang telah mereka pelajari dan menguji pengetahuan dan kemampuan mereka yang sekarang. Hasil penelitian Indah (2011) menyatakan bahwa Strategi Peninjauan Kembali ala permaian "Holly-wood Square" dapat meningkat pemahaman mahasiswa terhadap prosedur dan bukti audit pada mahasiswa Universitas Negeri Semarang. Sehingga dapat dihipotesiskan bahwa :

$\mathrm{H}_{1}$ : Strategi Peninjauan Kembali sebagai aktivitas yang dapat meningkatkan pemahaman mahasiswa terhadap mata kuliah Pengantar Akuntansi

\section{Kerangka Pemikiran Teoritis}

Berdasarkan uraian di atas dapat digambarkan Kerangka Pemikiran Teoritis sebagai berikut : 


\section{Gambar 1. Kerangka Pemikiran Teoritis}

\section{Strategi Peninjauan Kembali melalui permainan dalam kelas pada mata kuliah Pengantar Akuntansi}

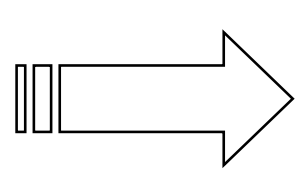

\section{METODE PENELITIAN \\ Rancangan Penelitian}

Rancangan penelitian ini meliputi beberapa tahap yaitu tahap perencanaan (planning), pelaksanaan (acting) dan obsevasi. Perencanaan (planning) meliputi membuat skenario pembelajaran, membuat lembar observasi untuk melihat suasana pembelajaran, dan aktivitas mahasiswa, membuat dan menyediakan media pembelajaran mata kuliah Pengantar Akuntansi serta mendesain alat evaluasi untuk melihat apakah mahasiswa dengan menggunakan Strategi Peninjauan Kembali melalui permainan dalam kelas dapat meningkatkan hasil belajar. Pelaksanaan (acting) merupakan suatu kegiatan dilaksanakannya skenario pembelajaran yang telah direncanakan. Prosedur Strategi Peninjauan Kembali melalui permainan dalam kelas dapat di lihat dalam gambar 1.1 di bawah ini :

\section{Gbr 1.1}

\section{Prosedur Strategi Peninjauan Kembali Melalui Permainan Dalam Kelas}

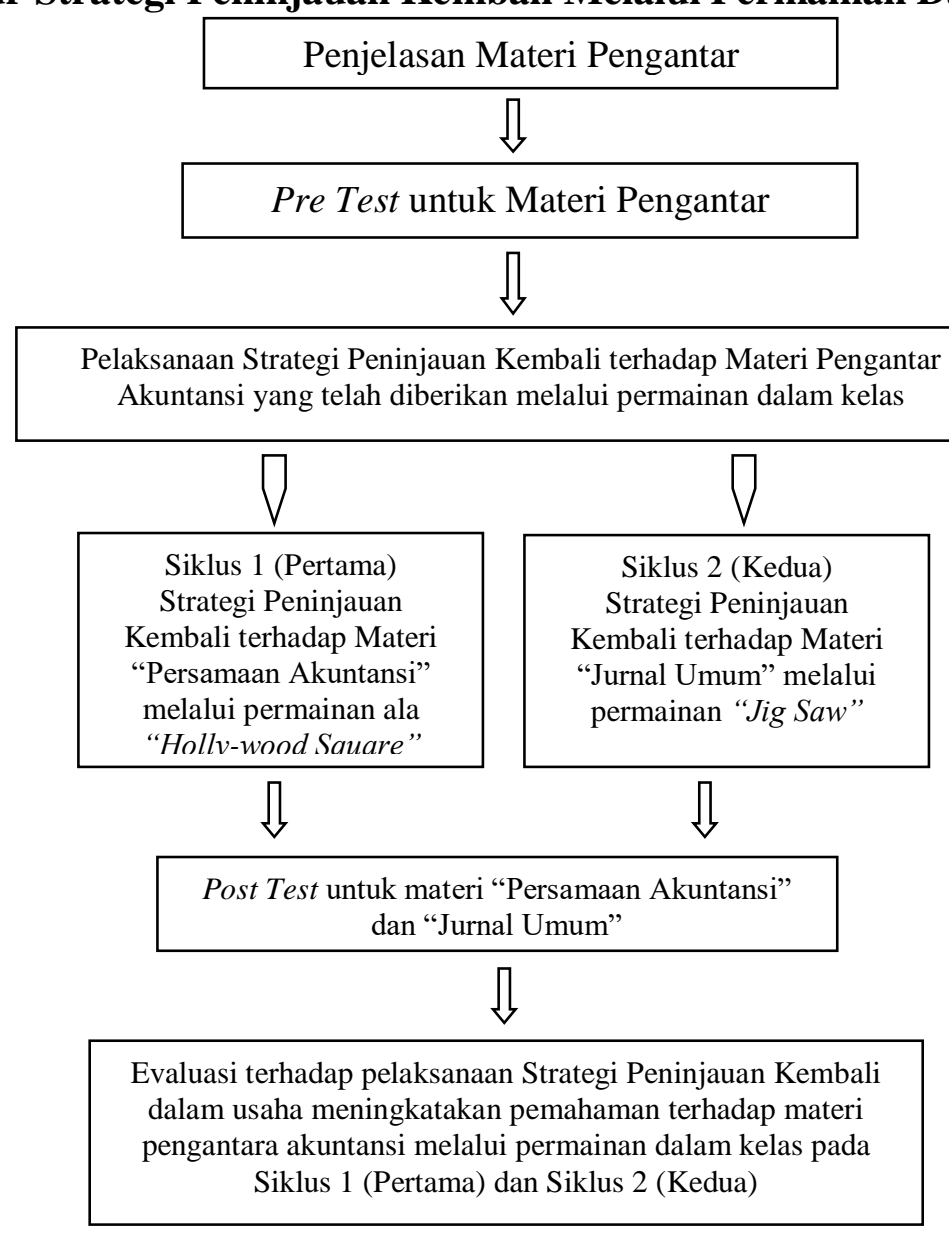




\section{Obyek Penelitian}

Penelitian ini dilaksanakan pada mahasiswa Semester 1 Program Studi Akuntansi Jenjang S1 di Jurusan Akuntansi Fakultas Ekonomi Universitas Semarang yang mengikuti mata kuliah Pengantar Akuntansi. Penelitian ini dilakukan pada semester ganjil tahun ajaran 2013/2014 yang terdiri dari 2 (dua) kelas yaitu kelas B yang berjumlah 54 mahasiswa dan Kelas $C$ yang berjumlah 60 mahasiswa.

\section{Metode Pengumpulan Data}

\section{Dokumentasi}

Metode pengumpulan data yang dilakukan adalah sebagai berikut :

Dokumentasi adalah metode pengumpulan data dengan menggunakan dokumendokumen sebagai bahan acuan untuk kepentingan penelitian. Dalam penelitian ini yang digunakan adalah daftar nilai mata kuliah Pengantar Akuntansi dan dokumentasi kegiatan pada masing-masing siklus.

\section{Metode tes}

Tes yang digunakan dalam penelitian ini adalah tes prestasi yaitu tes yang digunakan untuk mengukur kemampuan mahasiswa setelah mengerjakan sesuatu. Tes disini berupa pre test dan post test (Indah, 2011).

\section{Metode Observasi}

Observasi adalah pengamatan yang dilakukan pada subyek penelitian. Aspek yang diamati dalam penelitian ini adalah perhatian mahasiswa dalam menerima pembelajaran, bahasa yang digunakan dosen dalam pembelajaran, motivasi dalam menerima pelajaran, kerjasama dan partisipasi mahasiswa dalam proses pembelajaran (Indah, 2011).

\section{Jurnal}

Jurnal mahasiswa dan pengajar diisi pada akhir pembelajaran. Jurnal mahasiswa berisi tentang kesulitan mahasiswa dalam pembelajaran, pendapat atau komentar mahasiswa pada Strategi Peninjauan Kembali melalui permainan dalam kelas ala Permainan "Holly-wood Squares" dan JigSaw yang dilakukan oleh pengajar dan pesan, kesan ataupun saran tentang pembelajaran tersebut (Indah, 2011).

\section{Analisis Data}

Analisis data yang digunakan adalah analisis deskriptif prosentase. Analisis data ini digunakan untuk menganalisis mengenai prosentase hasil dari pre test dan post test yang dilakukan oleh dosen pada saat pelaksanaan tindakan. Sedangkan untuk mengetahui sejauhmana Strategi Peninjauan Kembali melalui permainan dalam kelas dapat meningkatkan kemampuan belajar mahasiswa dilihat dari hasil belajar mahasiswa yaitu dengan cara total skor dari satu kelas dibagi dengan jumlah mahasiswa sehingga dapat diketahui skor rata-rata hasil belajar di kelas tersebut, skor rata-rata tersebut dibandingkan antar siklus.

\section{Ruang Lingkup Materi Mata Kuliah Pengantar Akuntansi}

Mata kuliah ini membahas prinsip-prinsip dan praktek-praktek akuntansi, siklus akuntansi yang dimulai dari proses pencatatan transaksi (jurnal), pembukuan (posting), neraca lajur, serta penyusunan laporan keuangan pada suatu unit usaha atau perusahaan. Mata kuliah ini memberikan pemahaman dan pengetahuan tentang dasar akuntansi keuangan, persamaan akuntansi, teknik pemrosesan data akuntansi yang meliputi jurnal, buku besar, neraca lajur serta dasar penyusunan laporan keuangan baik untuk perusahaan jasa dan perusahaan dagang. 


\section{Indikator Keberhasilan}

Indikator keberhasilan dari tindakan yang dilakukan dapat diukur melalui beberapa cara. Pertama, keberhasilan akan dilihat dari hasil skor dari mahasiswa yang berhasil menjawab pertanyaan dengan benar. Kedua, antusias mahasiswa dalam belajar mata kuliah Pengantar Akuntansi. Ketiga, ketrampilan dosen dalam mengembangkan desain dan strategi pembelajaran meningkat. Keempat, hasil belajar mahasiswa meningkat dengan ditunjukkan terjadinya peningkatan rata-rata kelas .

\section{PEMBAHASAN}

\section{Deskriptif Obyek Penelitian}

Pelaksanaan penelitian ini dilakukan pada mahasiswa semester 1 (satu) Program Studi Akuntansi S1 di Jurusan Akuntansi Fakultas Ekonomi Universitas Semarang yang mengikuti atau mengambil mata kuliah Pengantar Akuntansi. Mata kuliah ini merupakan kelompok mata kuliah keilmuan dan ketrampilan (MKK), dengan bobot 4 SKS dimana 3 SKS merupakan teori dan 1 SKS adalah praktikum. Penelitian ini dilakukan pada semester ganjil tahun ajaran 2013/2014 yang terdiri dari 2 (dua) kelas Pengantar Akuntansi yaitu kelas B dan Kelas C. Jumlah responden dalam penelitian ini adalah 54 mahasiswa untuk kelas B dan 60 mahasiswa untuk kelas C.

\section{Hasil Observasi \\ Siklus I (Pertama) \\ Persiapan Siklus I}

Strategi Peninjauan Kembali melalui permainan dalam kelas pada siklus I menggunakan permainan ala "Holly-wood Square". Siklus I dilakukan pada materi Pengantar Akuntansi yaitu materi "Persamaan Akuntansi". Materi "persamaan akuntansi" diberikan kepada mahasiswa pada pertemuan kedua. Peneliti yang merupakan pengampu mata kuliah pengantar akuntansi memberikan penjelasan materi "persamaan akuntansi" melalui ceramah dan pembahasan latihan soal kepada mahasiswa di kelas B dan Kelas C.

\section{Pelaksanaan Pre-test materi "persamaan akuntansi"}

Pre-test dilakukan sebelum pelaksanaan siklus I. Pre test diberikan kepada mahasiswa dimaksudkan untuk mengetahui seberapa tingkat pemahaman mahasiswa terhadap materi "persamaan akuntansi" sebelum dilakukannya strategi peninjauan kembali melalui permaianan dalam kelas. Pre test berisikan 28 item pertanyaan mengenai materi "persamaan akuntansi". Adapun hasil pre-test dari kelas B dan kelas C dapat dilihat dalam tabel 4.3 dibawah ini :

\section{Tabel 4.3}

\section{Hasil Pre-test Siklus I}

\begin{tabular}{|c|c|c|}
\hline Nilai & Kelas B & Kelas C \\
\hline Terendah & 23.21 & 10.7 \\
\hline Tertinggi & $\mathbf{9 8 . 2 1}$ & 94.6 \\
\hline Rata-rata kelas & 66.98 & 61.8 \\
\hline Jumlah Mahasiswa & 53 & 59 \\
\hline
\end{tabular}

Berdasarkan tabel 4.3 diketahui hasil pre test untuk materi persamaan akuntansi pada siklus I, untuk kelas B diketahui nilai terrendah adalah sebesar 23.21, sedangkan nilai tertinggi adalah 98.21. Untuk rata-rata kelas di kelas B adalah sebesar 66.98. Nilai 
terendah di kelas $\mathrm{C}$ adalah sebesar 10.7 dan nilai tertinggi adalah 94.6. Sedangkan untuk rata-rata kelas di kelas $\mathrm{C}$ adalah sebesar 61.8.

Pelaksanaan Strategi Peninjauan Kembali melalui permaianan ala "Holly-wood Square"

Peneliti membuat pertanyaan sebanyak 27 pertanyaan mengenai materi persamaan akuntansi yang harus dipilih oleh kontestan dan dijawab oleh selebritis. Pertanyaan dibuat dalam selembar kertas dan dikumpulkan menjadi satu disebuah meja. Setelah itu, peneliti mensimulasikan format tayangan permainan tic-tac-toe yang digunakan dalam "Holly-wood Square" dengan menata sembilan kursi secara sejajar didepan kelas yang berfungsi sebagai tempat untuk para "selebriti". Sedangkan "kontestan" duduk persis berada didepan para "selebriti".

Setelah itu peneliti memberikan kepada sembilan "selebritis" masing-masing sebuah kartu dengan tanda "X", "O", dan "\#" disatu sisi. Sisi yang diberi tanda "X", "O" dan "\#” akan dibalik oleh "selebriti" apabila mereka berhasil menjawab pertanyaan yang diberikan oleh "kontestan". Kemudian peneliti menuliskan urutan nomor pertanyaan dari nomor 1 sampai dengan 27 di papan tulis.

Selanjutnya para "kontestan" memilih nomor urut pertanyaan yang telah tersedia sesuai dengan keinginan mereka, dan menunjuk siapa dari para "selebriti" yang harus menjawab pertanyaan yang telah dipilih oleh "kontestan". Tugas "kontestan" selanjutnya adalah memberikan jawaban "setuju" atau "tidak setuju" atas jawaban dari "selebriti", beserta alasan mengapa kontestan "setuju" ataupun "tidak setuju" atas jawaban dari "selebriti". Disini peneliti berfungsi sebagai penengah apabila terjadi perbedaan jawaban antara "selebriti" dengan "kontestan".

Bagi mahasiswa yang tidak bertugas baik sebagai "selebriti" maupun "kontestan", mereka dipilih secara acak oleh peneliti untuk mengulang kembali jawaban yang diberikan oleh "selebriti" serta alasan dari jawaban tersebut yang diberikan oleh "kontestan". Rotasi dilakukan pada para "selebriti" dan "kontestan". Pada kelas B yang terdiri dari 6 kelompok, maka strategi peninjauan kembali melalui permaiana ala "Holly-wood Square" dilakukan sampai dengan 3 putaran. Sedangkan untuk kelas $\mathrm{C}$ yang terdiri dari 7 kelompok, maka strategi peninjauan kembali melalui permaianan ala "Holly-wood Square" dilakukan sampai dengan 4 putaran.

Pelaksanaan post-test materi persamaan akuntansi setelah dilakukannya strategi Peninjauan Kembali melalui permaianan ala "Holly-wood Square"

Post-test dilakukan setelah pelaksanaan siklus I yaitu pada pertemuan keempat. Adapun hasil post-test dari kelas B dapat dilihat dalam tabel 4.5, sedangkan untuk kelas C dapat dilihat dalam tabel 4.6 dibawah ini :

Tabel 4.5

Perbandingan Hasil Pre-test dan Post Test Kelas B

\begin{tabular}{|c|c|c|}
\hline \multirow{2}{*}{ Nilai } & \multicolumn{2}{|c|}{ Kelas B } \\
\cline { 2 - 3 } & Pre Test & Post Test \\
\hline Terendah & $\mathbf{2 3 . 2 1}$ & $\mathbf{5 0}$ \\
\hline Tertinggi & $\mathbf{9 8 . 2 1}$ & $\mathbf{9 6 . 4 3}$ \\
\hline Rata-rata kelas & 66.98 & 78.87 \\
\hline
\end{tabular}

Sumber : Data yang diolah, 2013

Berdasarkan tabel 4.5, terjadinya peningkatan nilai yang diperoleh mahasiswa di kelas B sebelum dilakukan strategi peninjauan kembali dan setelah dilakukan strategi peninjauan kembali. Nilai terendah pada saat pre-test adalah sebesar 23.21 meningkat menjadi 50 pada saat post-test. Nilai tertinggi pada saat pre-test adalah sebesar 98.21 
mengalami penurunan menjadi 96.43. Akan tetapi rata-rata kelas untuk kelas B mengalami peningkatan dari 66.98 menjadi 78.87 .

Tabel 4.6

Perbandingan Hasil Pre-test dan Post Test Kelas C

\begin{tabular}{|c|c|c|}
\hline \multirow{2}{*}{ Nilai } & \multicolumn{2}{|c|}{ Kelas C } \\
\cline { 2 - 3 } & Pre Test & Post Test \\
\hline Terendah & 10.7 & 42.9 \\
\hline Tertinggi & 94.6 & 98.2 \\
\hline Rata-Rata kelas & 61.8 & 85.3 \\
\hline
\end{tabular}

Sumber : Data diolah, 2013

Nilai terendah yang diperoleh di kelas $\mathrm{C}$ pada saat pre-test adalah sebesar 10.7, dimana mengalami peningkatan menjadi 42.9. Untuk pre-test nilai tertinggi yang diperoleh sebesar 94.6 meningkat menjadi 98.2. Rata-rata kelas mengalami peningkatan dari 61.8 pada saat pre-test menjadi 85.3 setelah post-test.

\section{Evaluasi Pelaksanaan Strategi Peninjauan Kembali pada Siklus I}

Evaluasi pada siklus I adalah kurangnya kerjasama kelompok di dalam menyelesaikan atau menjawab pertanyaa. Hal ini terlihat pada saat salah satu anggota dari selebritis mendapatkan tugas untuk menjawab pertanyaan yang diberikan oleh kelompok kontestan, anggota tersebut masih bekerja sendiri. Tidak ada teman dalam satu kelompoknya yang berusaha untuk membantu anggota tersebut, hal ini juga berlaku pada kelompok kontestan.

Untuk mahasiswa yang tidak bertugas sebagai selebritis ataupun kontestan, pada saat putaran ke-2, para mahasiswa yang tidak bertugas masih memiliki perhatian yang tinggi terhadap jalannya permainan, dikarenakan masih banyak mahasiswa yang belum mendapatkan tugas untuk mengulang kembali apa jawaban serta alasan dari pertanyaan yang diberikan. Memasuki putaran ke-3, perhatian mahasiswa banyak berkurang karena sudah banyak mahasiswa yang mendapatakan giliran untuk mengulang kembali jawaban serta alasan dari pertanyaan yang diberikan. Sehingga dapat disimpulkan bahwa masih kurangnya keaktifan mahasiswa baik secara individu maupun kelompok di dalam menjawab pertanyaan.

\section{Siklus II (Kedua)}

\section{Persiapan Siklus II}

Berdasarkan evaluasi pada pelaksanaan siklus I, maka pada pelaksanaan startegi peninjauan kembali pada siklus II peneliti tidak menggunakan permainan ala "Hollywood Square” tetapi menggunakan permaian “Jigsaw”. Siklus II dilakukan pada materi Pengantar Akuntansi yaitu materi "Jurnal Umum".

\section{Pelaksanaan Pre-test materi "Jurnal Umum"}

Pre-test dilakukan sebelum pelaksanaan siklus II. Pre test diberikan kepada mahasiswa dimaksudkan untuk mengetahui seberapa tingkat pemahaman mahasiswa terhadap materi "Jurnal Umum" sebelum dilakukannya strategi peninjauan kembali melalui permaianan dalam kelas. Pre test berisikan 26 item pertanyaan mengenai materi "Jurnal Umum". Adapun hasil pre-test dari kelas B dan kelas C dapat dilihat dalam tabel 4.7 dibawah ini : 
Tabel 4.7

Hasil Pre-test Siklus II

\begin{tabular}{|c|c|c|}
\hline Nilai & Kelas B & Kelas C \\
\hline Terendah & 3.8 & 19.2 \\
\hline Tertinggi & $\mathbf{8 6 . 5}$ & $\mathbf{9 6 . 2}$ \\
\hline Rata-rata kelas & $\mathbf{3 8 . 8}$ & $\mathbf{5 9 . 5}$ \\
\hline Jumlah Mahasiswa & 52 & 59 \\
\hline
\end{tabular}

Sumber : Data yang diolah, 2013

Berdasarkan tabel 4.7 diketahui hasil pre test untuk materi "Jurnal Umum" pada siklus II, untuk kelas B dari 52 mahasiswa nilai terendah adalah sebesar 3.8 sedangkan nilai tertinggi 86.5. Untuk rata-rata kelas di kelas B sebesar 38.8. Nilai terendah di kelas C sebesar 19.2 dan nilai tertinggi adalah 96.2. Untuk rata-rata kelas di kelas $\mathrm{C}$ adalah sebesar 59.5.

\section{Pelaksanaan Strategi Peninjauan Kembali melalui permaianan "Jigsaw"}

Peneliti membuat pertanyaan sebanyak 27 pertanyaan mengenai materi "Jurnal Umum". Pertanyaan sebanyak 27 dibagi ke dalam 3 kali putaran permainan. Satu kali permainan terdiri dari 9 pertanyaan disesuaikan dengan jumlah anggota dalam satu kelompok. Sehingga dalam satu kelompok terdapat 9 nomor pertanyaan.

Pada saat permainan dimulai, anggota yang memiliki nomor soal yang sama berkumpul menjadi satu kelompok untuk bersama-sama membahas pertanyaan yang diberikan. Disini peneliti bertugas memeriksa jawaban dan membantu kelompok yang menemui kesulitan dalam menjawab pertanyaan.

Selanjutnya anggota yang tergabung dalam kelompok sesuai dengan nomor pertanyaan, bergabung kembali ke kelompok asal. Disini masing-masing anggota harus menjelaskan kepada anggota yang lain mengenai jawaban dari pertanyaan dimulai dari soal nomor 1 sampai dengan nomor 9.

Kemudian peneliti akan memulai permainan dengan memberikan pertanyaan dimana apabila pertanyaan yang dikeluarkan adalah pertanyaan nomor satu maka anggota yang bertugas memegang soal nomor satu tidak diperkenankan untuk menjawab. Peneliti akan menyebutkan anggota dengan nomor berapa yang diperbolehkan menjawab soal yang diberikan.

\section{Pelaksanaan post-test materi persamaan akuntansi setelah dilakukannya strategi Peninjauan Kembali melalui permaianan "Jigsaw"}

Post-test dilakukan setelah pelaksanaan siklus II yaitu pada pertemuan kedelapan. Post test diberikan kepada mahasiswa dimaksudkan untuk mengetahui seberapa tingkat pemahaman mahasiswa mengalami kemajuan terhadap materi "jurnal umum" setelah dilakukannya strategi peninjauan kembali melalui permaianan dalam kelas. Soal untuk post-test berisikan 27 item pertanyaan mengenai materi "Jurnal Umum”. Adapun hasil post-test dari kelas B dapat dilihat dalam tabel 4.8, sedangkan untuk kelas $\mathrm{C}$ dapat dilihat dalam tabel 4.9 dibawah ini : 
Tabel 4.8

Perbandingan Hasil Pre-test dan Post Test Kelas B

\begin{tabular}{|c|c|c|}
\hline \multirow{2}{*}{ Nilai } & \multicolumn{2}{|c|}{ Kelas B } \\
\cline { 2 - 3 } & Pre Test & Post Test \\
\hline Terendah & 3.8 & 51.9 \\
\hline Tertinggi & 86.5 & 96.3 \\
\hline Rata-rata kelas & 38.8 & 81.6 \\
\hline
\end{tabular}

Sumber : Data yang diolah, 2013

Berdasarkan tabel 4.8, terjadinya peningkatan nilai yang diperoleh mahasiswa di kelas B sebelum dilakukan strategi peninjauan kembali dan setelah dilakukan strategi peninjauan kembali. Untuk nilai terendah pada saat pre-test sebesar 3.8 meningkat menjadi 51.9. Nilai tertinggi dari 86.5 menjadi 96.3 pada saat post test. Untuk rata-rata kelas dari 38.8 pada saat pre-test menjadi 81.6 pada saat post-test.

\section{Tabel 4.9}

Perbandingan Hasil Pre-test dan Post Test Kelas C

\begin{tabular}{|c|c|c|}
\hline \multirow{2}{*}{ Nilai } & \multicolumn{2}{|c|}{ Kelas C } \\
\cline { 2 - 3 } & Pre Test & Post Test \\
\hline Terendah & 19.2 & 33.3 \\
\hline Tertinggi & 96.2 & 100 \\
\hline Rata-Rata kelas & 59.5 & 69.5 \\
\hline
\end{tabular}

Sumber : Data diolah, 2013

Sama halnya dengan yang terkjadi pada kelas B, di kelas C juga terjadi peningkatan perolehan nilai setelah dilakukannya strategi peninjaun kembali. Berdasarkan tabel 4.9, untuk nilai terendah pada saat pre-test adalah sebesar 19.2 meningkat menjadi 33.33. Sedangkan nilai tertinggi dari 96.2 pada saat pre-test menjadi 100 setelah dilakukan strategi peninjauan kembali. Untuk rata-rata kelas mengalami peningkatan dari 59.5 menjadi 69.5 pada saat post-test.

\section{Evaluasi Pelaksanaan Strategi Peninjauan Kembali pada Siklus II}

Mahasiswa pada pelaksanaan siklus II terlihat lebih antusias dibandingkan pada siklus I. Pada siklus II mahasiswa aktif baik secara individu maupun kelompok dalam menyelesaikan dan menjawabn pertanyaan yang diberikan pada siklus II. Kerjasama dalam kelompok terlihat pada saat mahasiswa secara berkelompok harus menyelesaikan atau mencari jawaban dari pertanyaan yang diberikan pada siklus II. Keaktifan mahasiswa secara individu terlihat pada saat setiap mahasiswa harus berusaha untuk menjelaskan kembali jawaban dari pertanyaan yang mereka peroleh kepada temanteman satu kelompoknya. Keaktifan mahasiswa semakin terlihat pada saat mahasiswa berusaha menjawab kembali pertanyaan-pertanyaan yang diberikan kepada mereka.

\section{HASIL DAN PEMBAHASAN}

\section{Pembahasan}

Strategi peninjauan kembali melalui permainan dalam kelas memiliki manfaat yang banyak saat diterapkan pada mata kuliah Pengantar Akuntansi. Pada mata kuliah Pengantar Akuntansi mahasiswa dituntut untuk paham mengenai materi yang diberikan, sehingga salah satu cara untuk membuat pembelajaran tetap melekat dalam pikiran adalah dengan mengalokasikan waktu untuk meninjau kembali apa yang telah dipelajari. Melalui tindakan kelas berupa strategi peninjauan kembali dapat membantu mahasiswa untuk memikirkan kembali informasi atau materi yang telah mereka peroleh dan menemukan cara untuk menyimpan kembali materi yang telah mereka peroleh di dalam ingatan mereka. Hal ini dapat dilihat pada tabel 4.8 dan 4.9 bahwa terjadinya 
peningkatan rata-rata kelas dari sebelum dilaksanakannya strategi peninjauan kembali dengan setelah dilaksanakannya strategi peninjauan kembali.

Strategi peninjuan kembali mejadi aktivitas yang menyenangkan karena dilakukan melalui permainan dalam kelas, sehingga mahasiswa tidak merasakan aktivitas mengingat kembali materi yang sudah diberikan sebagai aktivitas yang membosankan. Pada setiap pelaksanaan siklus, mahasiswa lebih bersemangat dan mempunyai minat untuk berusaha menyelesaikan dan menjawan setiap pertanyaan yang mereka peroleh. Terutama pada pelaksanaan siklus II, mahasiswa terlihat sangat bersemangat dan lebih berminat dibandingkan dengan pelaksanaan siklus I. Aktivitas dosen pada setiap siklus baik siklu I dan siklus IIadalah sebagai fasilitator atau penengah apabila terjadi ketidaksesuaian jawaban yang dibuat oleh mahasiswa dengan pertanyaan yang diberikan. Minat, keaktifan dan kerjasama mahasiswa dalam proses pembelajaran mata kuliah Pengantar Akuntansi melalui strategi peninjauan kembali dapat dilihat dalam tabel 4.10 berikut ini :

Tabel 4.10

Data Hasil Observasi mengenai Minat, Keaktifan, dan Kerjasama Mahasiswa

\begin{tabular}{|c|l|c|c|c|}
\hline \multirow{2}{*}{ No } & \multicolumn{1}{|c|}{ Variabel yang diamati } & \multicolumn{2}{c|}{ Skor Observer } & \multirow{2}{*}{ Rerata } \\
\cline { 3 - 4 } & \multicolumn{1}{|c|}{ Siklus 1 } & Siklus 2 & \\
\hline 1. & Minat Mahasiswa & 3,5 & 4 & 3,75 \\
\hline 2. & Keaktifan & 3 & 4 & 3,5 \\
\hline 3. & $\begin{array}{l}\text { Kerjasama Mahasiswa dalam proses } \\
\text { pembelajaran }\end{array}$ & 2,5 & 4 & 3,25 \\
\hline \multicolumn{2}{|c|}{ Rerata } & 3,5 \\
\hline
\end{tabular}

Sumber : Data diolah, 2013

Berdasarkan tabel 4.10 di atas menunjukkan secara keseluruhan dari aspek yang diamati oleh dosen mengenai mahasiswa dapat dikategorikan baik dengan rerata sebesar 3,5. Tabel tersebut juga menunjukkan adanya peningkatan minat, keaktifan dan kerjasama mahasiswa dari siklus I ke siklus II.

Adanya kegiatan permainan dalam proses pembelajaran memberikan keuntungan dimana mahasiswa tidak merasakan jenuh dalam proses pembelajaran, selanjutnya mahasiswa secara individu dapat mengembangkan daya pikir dann kreatif mereka, menganalisis jawaban secara cepat dan tepat. Secara kelompok dapat memperbaiki hubungan sosial dengan adanya kerjasama yang lebih baik antara mahasiswa satu dengan yang lainnya.

Keuntungan lainnya dari penerapan strategi peninjauan kembali melalui permainan dalam kelas adalah pemahaman mahasiswa mengenai suatu materi akan menjadi lebih mendalam. Hal ini karena tidak semua mahasiswa memiliki daya tangkap yang cepat terhadap materi yang diberikan. Sehingga mahasiswa memerlukan peninjauan kembali mengenai materi yang diberikan tersebut. Dengan adanya peninjauan kembali mengenai materi yang diberikan melalui permaianan, diharapkan aktivitas mengingat kembali materi yang sudah diberikan sebagai aktivitas yang membosankan.

\section{PENUTUP}

\section{Kesimpulan}

Hasil penelitian menunjukkan prestasi belajar mahasiswa mengalami peningkatan si setiap siklus yaitu siklus I dan siklus II. Hasil tes mahasiswa sebelum Strategi Peninjauan Kembali Melalui Permaianan Dalam Kelas yang diterapkan di dua kelas yaitu kelas B dan kelas C mengalami peningkatan. Hasil rata-rata kelas siklus I 
pada kelas B sebelum Strategi Peninjauan kembali adalah 66,98 mengalami peningkatan setelah pelaksanaan Strategi Peninjauan Kembali menjadi 78,87. Sedangkan untuk kelas C hasil rata-rata kelas siklus I sebelum Strategi Peninjauan Kembali sebesar 61,8 juga mengalami peningkatan menjadi 85,3 setelah penerapan strategi peninjauan kembali. Untuk hasil rata-rata kelas pada siklus II juga mengalami peningkatan seperti pada siklus I. Nilai rata-rata kelas pada siklus II di kelas B, sebelum strategi peninjauan kembali 3,8 mengalami peningkatan menjadi 81,6 setelah adanya strategi peninjauan kembali. Begitupula halnya dengan kelas $\mathrm{C}$, pada siklus II setelah strategi peninjauan kembali rata-rata kelas sebesar 69,5 dari yang semula sebelum pelaksanaan strategi peninjauan kembali rata-rata kelasnya dalah 59,5.

Hasil pengamatan dosen mengenai minat, keaktifan dan kerjasama mahasiswa dalam proses pembelajaran rentangan 1-4 hasilnya baik yaitu 3,5. Skor tersebut merupakan rerata dari seluruh aspek yang diamati pada dua siklus.

\section{Saran}

Berdasarkan hasil penelitian yang diperoleh maka saran yang dapat diberikan adalah untuk dapat menerapkan Strategi Peninjauan Kembali Melalui Permainan Dalam Kelas di dalam pembelajaran mata kuliah Pengantar Akuntansi. Metode ini terbukti dapat meningkatakan kemampuan mahasiswa dalam memahami materi pengantar akuntansi, meningkatkan keaktifan mahasiswa dan kerja sama mahasiswa dalam kelompok.

\section{Keterbatasan Penelitian}

Keterbatasan yang terjadi dalam pelaksanaan penelitian ini adalah :

1. Keterbatasan besarnya ruang kelas yang mempengaruhi mahasiswa di dalam aktivitas mereka dalam pelaksanaan Strategi Peninjauan Kembali melalui permainan kelas.

2. Pelaksanaan pre-test dan post test yang masih bersifat terbuka. Sehingga memungkinkan dapat mempengaruhi hasil pre-test dan post-test yang dilakukan.

3. Kurangnya variasi soal yang diberikan pada saat pelaksanaan Strategi Peninjauan Kembali.

\section{Saran Penelitian Selanjutnya}

Saran yang diberikan untuk penelitian selanjutnya mengenai Startegi Peninjauan Kembali adalah :

1. Lebih baik menggunakan ruang kelas yang besar sehingga aktivitas mahasiswa pada saat permainan diterapkan tidak terganggu.

2. Dalam pelaksanaan pre-test dan post-test bisa dilakukan secara tertutup. Sehingga hasil pre-test dan post-test yang dilakukan diharapkan dapat mencerminkan hasil yang sebenarnya.

3. Menambah variasi soal sehingga dapat mengembangkan pikiran dan daya kreatif mahasiswa. 


\section{DAFTAR PUSTAKA}

Asnida, Selma, Zarinah, S; Katrie \& W.S Chiong. (2006). Pembelajaran Kooperatif Yang www.geocities.com/gerdner028/ilmiahl.htm. Diakses pada tanggal 20 Juni 2007.

B.Bennett, C. Rolheiser-Bennett, L.Stevann (1991). Cooperative Learing Where Heart Meets Mind. Tersedia pada http:// www.geocities.com/ Cooperative Learing/ilmiahl.htm. Diakses pada tanggal 29 Juni 2007.

Indah Anisykurlillah. (2011). Peningkatan Pemahaman Mahasiswa Terhadap Prosedur dan Bukti Audit Dengan Strategi Peninjauan Kembali Ala Permainan "HollyWood Squares”. Simposium Nasional Akuntansi XIV. Aceh. 2011.

Johnson, \& Johnson, R.T (1991). Learrning together and alone : Cooperative, Competitive, and individualistic learning (3rd Ed.). Upper Saddle river, NJ: Prentice-Hall.

LP3-ITB. 2003. Ketrampilan Belajar. Tersedia pada http:// www.itb.co.id/lp3/ketrampilan belajar.htm. Diakses pada tanggal 25 Juni 2007.

Silberman, Melvin. 2006. Active Learning. Penerbit Nusa Media. Bandung. Slavin, R. (1990) Cooperative Learning : Theory, Research ang Practice. Englewood Cliff, NJ: Prentice Hall. 